\title{
Antioxidant activity of BHA, BHT and TBHQ examined with Miller's test
}

\author{
By M. Karamac, and R. Amarowicz \\ Division of Food Science, Institute of Animal Reproduction and Food \\ Research of Polish Academy of Sciences. Tuwima Street 10, P.O. Box 55 \\ 10-718 Olsztyn 5, Poland
}

\section{RESUMEN}

Actividad antioxidante de BHA, BHT y TBHQ examinada con el test de Miller.

En experimentos modelos usando el test de Miller, a $5 \mathrm{ml}$ de emulsión se añadió $25,12.5,6.25$ y $3.13 \mu g$ de BHA, BHT y TBHQ. Las relaciones inhibitorias (IR) para el BHA y BHT fueron similares. IR para TBHQ fue más baja que para BHA y BHT con niveles de adición del 6.25 y 3.13. Esto sugiere que en estudios modelos usando el test de Miller 25 $\mu \mathrm{g}$ de BHA, BHT, o TBHQ deben ser añadidos a $5 \mathrm{ml}$ de muestra control.

PALABRAS-CLAVE: Actividad antioxidante - Butil hidroquinona terciaria (TBHQ) - Butil hidroxianisol (BHA) Butilhidroxitolueno $(B H T)$ - Test de Miller.

\section{SUMMARY}

Antioxidant activity of BHA, BHT and TBHQ examined with Miller's test.

In model experiments with the use of Miller's test to $5 \mathrm{ml}$ emulsion 25, 12.5, 6.25 and $3.13 \mu \mathrm{g} \mathrm{BHA}$, BHT and TBHQ was added. Inhibitory ratios (IR) for BHA and BHT were similar. At addition level of 6.25 and 3.13 IR for TBHQ was lower than for $\mathrm{BHA}$ and $\mathrm{BHT}$. It is suggested that in the model studies with the use of Miller's test $25 \mu \mathrm{g} \mathrm{BHA}, \mathrm{BHT}$ or TBHQ should be added to $5 \mathrm{ml}$ of control sample.
KEY-WORDS: Antioxidant activity - Butylated hydroxyanisole (BHA) - Butylated hydroxytoluene (BHT) - Tertiary butyl hydroquinone (TBHQ) - Miller's test.

\section{INTRODUCTION}

Combined oxidation of B-carotene and linoleic acid was applied by Miller (8) in a test for determining activity of antioxidants. The test has been widely applied in the studies on antioxidant activity of natural compounds isolated from plant materials (1) (2) (3) (11) (12). Antioxidative activity of plant extracts, their fractions or pure compounds is often compared to the activity of synthetic antioxidants used in food technology. However, authors rarely report the concentration of these compounds in the samples tested or use various concentrations.

The aim of the study was to compare antioxidative properties of buthylated hydroxyanizol (BHA), buthylated toluene (BHT) and buthylated hydrochinone (TBHQ) (Fig. 1) in a test with B-carotene and linolenic acid and proposing addition of the antioxidants mentioned above to be applied as a standard to which activity of natural compounds of plant origin could be related.<smiles>COc1ccc(O)c(C(C)(C)C)c1</smiles>

$\mathrm{BHA}$<smiles>Cc1cc(C(C)(C)C)c(O)c(C(C)(C)C)c1</smiles>

$\mathrm{BHT}$<smiles>CC(C)(C)c1cc(O)ccc1O</smiles>

TBHQ

Figure 1

Chemical structure of $\mathrm{BHA}, \mathrm{BHT}$ and $\mathrm{TBHQ}$ 


\section{MATERIALS AND METHODS}

Model emulsion was prepared from linoleic acid, Bcarotene and Tween 40 according to Miller (8). To a series of tubes containing $5 \mathrm{ml}$ emulsion $0,2 \mathrm{ml}$ methanol with dissolved $25,12.5,6.25$, and $3.13 \mu \mathrm{g} \mathrm{BHA}$, BHT and TBHQ (all reagents by "Sigma") was added. Thus prepared samples were heated for $2 \mathrm{~h}$ in a water bath at $50^{\circ} \mathrm{C}$ measuring absorbance at $470 \mathrm{~nm}$ every $15 \mathrm{~min}$. Control sample contained $0.2 \mathrm{ml}$ pure methanol.

Antioxidative activity was expressed by inhibitory ratio (IR) adapted from a study by Kajimoto (7):

Inhibitory ratio $=\frac{A_{t}-A_{c t}}{A_{o}-A_{c t}} \times 100 \%$

$A_{0}$ - absorbance ot the sample before heating.

$A_{t}$ - absorbance of sample with addition of antioxidant heated for $t \mathrm{~min}$,

$A_{c t}$ - absorbance of control sample heated for $t$ min.
In all experiments, samples were analysed in triplicate and mean value \pm standard deviation were recorded. Significant differences between samples incubated with different addition of antioxidant were determined at 95\% level of probability using a t-Student test (5).

\section{RESULTS}

The results obtained are presented on Figs 2-4. After $15 \mathrm{~min}$ and $30 \mathrm{~min}$ heating at addition level of 25 and $12.5 \mu \mathrm{g} \mathrm{IR}$ for BHA and BHT was similar. Later, however, IR drop for BHA was faster. At addition of 6.25 and 3.13 $\mu \mathrm{g}$, at the beginning of heating $\mathrm{BHA}$ inhibited oxidation process stronger than BHT. As heating proceeded, IR diagrams approximated each other, and after $2 \mathrm{~h}$ of heating IR values were almost identical.

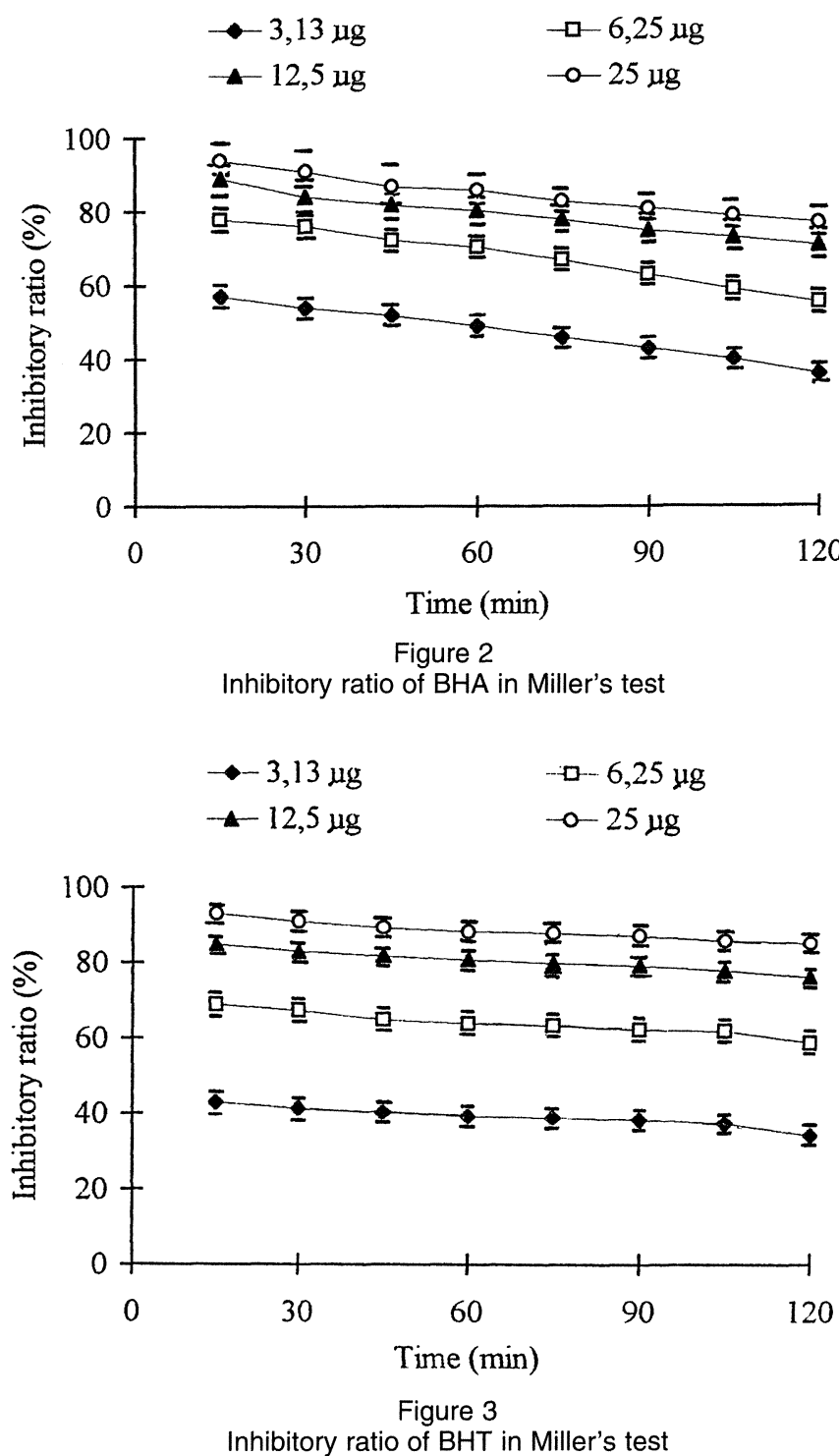




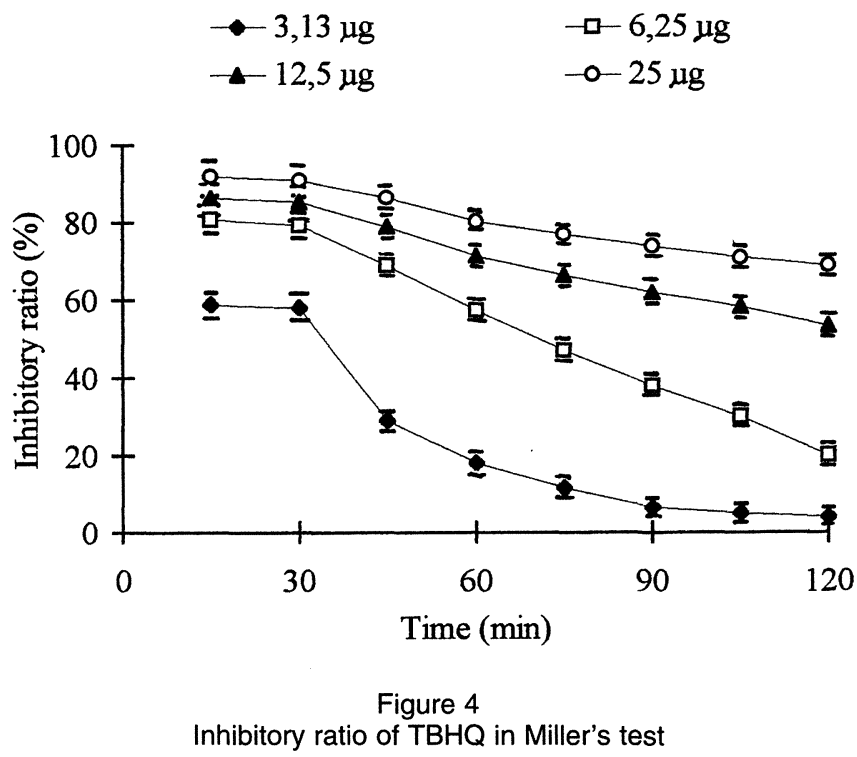

After 15 and 30 min of heating samples with addition of 25 and $12.5 \mu \mathrm{g}$ TBHQ IR values were similar as for $\mathrm{BHA}$ and $\mathrm{BHT}$. After 45 min of heating IR values for TBHQ diminished more than for BHA and BHT. Especially drastic drop in IR value was observed at addition of 6.25 and $3.13 \mu \mathrm{g} \mathrm{TBHQ}$. After $90 \mathrm{~min}$ of heating values at addition of $3.13 \mu \mathrm{g}$ TBHQ dropped below $10 \%$.

Differences in IR between the samples with 25 and $12.5 \mu \mathrm{g}$ and 12.5 and $6.55 \mu \mathrm{g}$ of added TBHQ were not significant only during first 30 min of experimentation (Fig. 4). The plot of RI for $12.5 \mu \mathrm{g}$ of $\mathrm{BHA}$ was situated below that for $25 \mu \mathrm{g}$ of BHA (Fig. 2). However, differences for these $\mathrm{RI}$ values during the whole period of incubation were statistically not significant. In all other cases differences in $\mathrm{RI}$ values for used additions of antioxidants were significant.

From literature data it follows that antioxidative activity of $\mathrm{BHA}, \mathrm{BHT}$ and TBHQ depends on the method used for model studies. Higher antioxidative activity of $\mathrm{BHA}$ than of BHT and manyfold lower for TBHQ was demonstrated in thin layer model system of methyl linoleate on cellulose (6). Berner et al. (4) reported antioxidative index in lard emulsion 30-fold higher for $\mathrm{BHA}$ than for TBHQ. Yet, in active oxigen method, antioxidant index for TBHQ was 3-fold higher than for $\mathrm{BHA}$ and $\mathrm{BHT}$. Higher antioxidative activity of $\mathrm{TBHQ}$ compared with BHA and BHT in model studies with soybean oil and chicken fat in emulsion versus dry oil tests was reported by Cort et al. (6). Relative effectiveness of antioxidants-linoleic acid monolayer on silica gel for TBHQ was almost the same as for BHT, while for BHA almost 3-fold higher (9). Relative effectiveness of red blood cell ghosts perfusion uptake for BHA was 2-fold higher than that for TBHQ (10).
To conclude, in model studies of natural antioxidative compounds or extracts with antioxidative properties using Miller's test, it is suggested to compare the results obtained to a sample containing $25 \mu \mathrm{g} \mathrm{BHA}, \mathrm{BHT}$ or TBHQ in $5 \mathrm{ml}$ model emulsion.

\section{REFERENCES}

1. Amarowicz, R., Wanasundara, U., Wanasundara, J. and Shahidi, F. (1993). - «Antioxidant activity of ethanolic extracts of flaxseed in a B-carotene-linoleate model system».- J. Food Lipids 1, 111-117.

2. Amarowicz, R. and Shahidi, F. (1995). - «Antioxidant activity of green tea catechins in a $B$-carotene-linoleate model system».- J. Food Lipids 2, 47-56.

3. Amarowicz, R., Formal, J. and Karamac M. (1995) -«Effects of seed moisture on phenolic acids in rapessed oil cake".- Grasas y Aceites 46, 354-356.

4. Berner, D. L., Conte, J. A. and Jacobson, G. A. (1974) -«Rapid method for determining antioxidant activity and fat stability".- J. Am. Oil Chem. Soc. 51, 292-296.

5. Bozyk, Z. and Rudzki, W. (1977). - «Metody Statystyczne w Badaniu Jakosci Produktów Zywnosciowych i Chemicznych».- WN-T, Warszawa.

6. Cort, W. M., Scott, J. W., Araujo, M., Mergens, W. J., Cannalonga, M. A., Osadca, M., Harley, H., Parrish, D. R., and Pool, W. R., (1975). - «Antioxidant activity and stability of 6-hydroxy-2, 5, 7, 8-tetramethyl chroman-2-carboxylic acid».- J. Am. Oil Chem. Soc. 52, 174-178.

7. Kajimoto, G. (1963). -«Antioxidative components and antiseptic components in tea leaves. I. Antioxidant action of materials extracted from leaves with alcohol and water".- Nippon Shokuhin Kogyo Gakkaishi 10, 1-8.

8. Miller, H. E. (1971). - «A simplified method for the evaluation of antioxidants».- J. Am. Oil Chem. Soc. 45 91.

9. Porter, W. L., Levasseur, L. A. and Henick, A. S. (1977). - Evaluation of some natural and synthetic phenolic 
antioxidants in linoleic acid monolayers on silica".- J. Food Sci. 42, 1533-1535.

10. Portet, W. L., Henick, A. S., Murphy F., Colgan, R. and Pofert G. (1978). - «Autoxidation and effects of pro-and antioxidants in lyophilized red blood cell membranes"-. Lipids 13, 137-144.

11. Shahidi, F., Wanasundara, U. and Amarowicz, R. (1994). -«Natural antioxidants from low-pungency mustard floue».- Food Res. Intern. 27, 489-493.

12. Wanasundara, U., Amarowicz, R. and Shahidi, F. (1994). - «Isolation and identification of an antioxidative component in canola meal».- J. Agric. Food Chem. 42, 1285-1290.

Recibido: Octubre 1996 Aceptado: Marzo 1997 